\title{
Microsatellite enhancers can be targeted to impair tumorigenesis
}

\author{
Kelsey E. Kaeding and Kenneth S. Zaret \\ Institute for Regenerative Medicine, Epigenetics Program, Department of Cell and Developmental Biology, Smilow Center for \\ Translational Research, Perelman School of Medicine, University of Pennsylvania, Philadelphia, Pennsylvania 19104, USA
}

\begin{abstract}
Dysregulation of repetitive elements has been implicated in many cancers and other human diseases; however, the role of repetitive elements remains largely unexplored. In this issue of Genes \& Development, Boulay and colleagues (pp. 1008-1019) explore the ability of GGAA repeats to act as alternative enhancers activated by EWS-FLI1 in Ewing sarcoma and contribute to tumorigenesis. Using CRISPR-mediated epigenome editing, repression of EWSFLI1 targeted microsatellite enhancers halted aberrant gene expression and impaired the growth of Ewing sarcoma xenografts in vivo. The study reveals the regulatory capacity of repetitive elements in cancer and offers insight into therapeutic targets for Ewing sarcoma.
\end{abstract}

Repetitive elements comprise $\sim 50 \%$ of the human genome; however, due to the difficulty of studying these elements both experimentally and computationally, their roles in gene expression remain largely unexplored (Lander et al. 2001). Recent studies have shown that dysregulation of repetitive elements is associated with cancers and other diseases; however, their contribution to disease progression has been unclear (Burns 2017).

In Ewing sarcoma, the second most common pediatric bone cancer, active enhancer-like GGAA repeats are a hallmark of the disease (Gangwal et al. 2008). Ewing sarcoma is commonly characterized by a chromosomal translocation that creates the fusion protein EWS-FLI1 from a fusion of the EWSR1 gene and the FLI1 transcription factor gene (Delattre et al. 1992). In Ewing sarcoma, EWS-FLI1 recruits the BRG1/BRM-associated factor (BAF) chromatin remodeling complex to tumor-specific enhancers and activates target genes (Boulay et al. 2017). The fusion protein gains the ability to activate GGAA microsatellite repeat elements as aberrant enhancers, induces changes in global H3K27ac, and reprograms enhancers genome-wide (Riggi et al. 2014). While the GGAA microsatellite regions acquire $\mathrm{H} 3 \mathrm{~K} 4 \mathrm{me} 1$ and $\mathrm{H} 3 \mathrm{~K} 27 \mathrm{ac}$ (Tomazou et al. 2015), which are epigenetic marks of active

[Keywords: Ewing sarcoma; pediatric cancer; epigenetics; EWS-FLI1; enhancer therapy; epigenome editing]

Corresponding author: zaret@pennmedicine.upenn.edu

Article is online at http://www.genesdev.org/cgi/doi/10.1101/gad.318105. 118 . enhancers, the functional consequences on gene expression and tumorigenesis resulting from these changes remain unexplored.

In this issue of Genes \& Development, Boulay et al. (2018) sought to understand how the usage of these alternative microsatellite enhancers can promote tumorigenesis and present an approach for selectively silencing repetitive elements. The investigators first confirmed the nascent activity of EWS-FLI1-bound GGAA repeat enhancers with NRO-seq (nuclear run-on experiments [NRO] combined with high-throughput sequencing), which confirmed the presence of repeat-derived enhancer RNAs that were sensitive to a knockdown of EWS-FLI1. They also silenced the GGAA repeats by targeting a CRISPRbased dCas9-KRAB, which led to local chromatin deacetylation and deposition of $\mathrm{H} 3 \mathrm{~K} 9 \mathrm{me} 3$. By targeting repeat enhancers acting upstream of critical Ewing sarcoma genes, including SOX2 and NKX2-2, they were able to greatly reduce both transcript and protein levels of these targets while avoiding disruption of neighboring repeat-associated genes. These findings demonstrate the ability to epigenetically target and silence specific GGAA repeats.

The investigators also sought to confirm the specificity of EWS-FLI1-bound GGAA repeat enhancers usage to Ewing sarcoma and indeed were able to confirm this by silencing these repeats in the NCI-H810 lung cancer cell line, which lacks EWS-FLI1. Upon dCas9-KRAB-mediated silencing of the repeats in NCI-H810 cells, no epigenetic marks of active enhancers were observed at the repeats, and no changes were observed in NKX2-2 or SOX2 transcript or protein levels. The investigators also showed that in mesenchymal stem cells where the NKX2-2 GGAA repeat enhancer had been initially silenced with dCas9-KRAB, when subsequently transduced with EWSFLI1, NKX2-2 induction was greatly impaired. However, expression of other genes targeted by EWS-FLI1 remained unchanged. Thus, EWS-FLI1 can convert silent GGAA repeats to active enhancers, and the GGAA enhancers are active only in Ewing sarcoma.

C) 2018 Kaeding and Zaret This article is distributed exclusively by Cold Spring Harbor Laboratory Press for the first six months after the full-issue publication date (see http://genesdev.cshlp.org/site/misc/terms.xhtml). After six months, it is available under a Creative Commons License (Attribution-NonCommercial 4.0 International), as described at http://creativecommons.org/licenses/by-nc/4.0/. 
Importantly, the investigators explored the effects of silencing GGAA repeats on tumorigenesis in vivo. In A673 and SKNMC Ewing sarcoma cell lines, they targeted and silenced an intergenic GGAA repeat enhancer that regulates, from a distance of $470 \mathrm{~kb}$, the $S O X 2$ locus, a gene critical for oncogenesis in Ewing sarcoma. The human cells were then injected into NOD-scidy (NSG) mice. The xenografts derived from these cancer cells exhibited striking reductions in both weight and volume compared with xenografts that lacked enhancer silencing. These findings show that the activation of the GGAA repeat enhancers by EWS-FLI1 significantly contributes to tumor growth in vivo.

In summary, the study from Boulay et al. (2018) showed that GGAA microsatellite enhancers that are activated by EWS-FLI1 act as critical regulators of the oncogenic program in Ewing sarcoma and that they can be selectively inhibited through epigenome-editing techniques. The study adds a significant example of the ability of repetitive elements to regulate gene expression and demonstrates how cancer cells can use novel regulatory networks to promote tumorigenesis. The approach to silence specific repetitive elements using epigenome editing ultimately impacted Ewing sarcoma tumor growth. Further research will be able to determine the applicability of these findings and approaches to additional cancer types.

\section{Acknowledgments}

Relevant work in the our laboratory is supported by National Institutes of Health (NIH) T32 HD083185 to K.E.K. and NIH 2P01GM099134 to K.S.Z.

\section{References}

Boulay G, Sandoval GJ, Riggi N, Iyer S, Buisson R, Naigles B, Awad ME, Rengarajan S, Volorio A, McBride MJ, et al. 2017. Cancer-specific retargeting of BAF complexes by a prion-like domain. Cell 171: 163-178.e19.

Boulay G, Volorio A, Iyer S, Broye LC, Stamenkovic I, Riggi N, Rivera MN. 2018. Epigenome editing of microsatellite repeats defines tumor-specific enhancer functions and dependencies. Genes Dev (this issue). doi: 10.1101/gad.315192.118.

Burns K. 2017. Transposable elements in cancer. Nat Rev Cancer 17: 415-424.

Delattre O, Zucman J, Plougastel B, Desmaze C, Melot T, Peter M, Kovar H, Joubert I, de Jong P, Rouleau G, et al. 1992. Gene fusion with an ETS DNA-binding domain caused by chromosome translocation in human tumours. Nature 359: $162-165$.

Gangwal K, Sankar S, Hollenhorst PC, Kinsey M, Haroldsen SC, Shah AA, Boucher KM, Watkins WS, Jorde LB, Graves BJ, et al. 2008. Microsatellites as EWS/FLI response elements in Ewing's sarcoma. Proc Natl Acad Sci 105: 10149-10154.

Lander ES, Linton LM, Birren B, Nusbaum C, Zody MC, Baldwin J, Devon K, Dewar K, Doyle M, FitzHugh W, et al. 2001. Initial sequencing and analysis of the human genome. Nature 409: 860-921.

Riggi N, Knoechel B, Gillespie SM, Rheinbay E, Boulay G, Suva ML, Rossetti NE, Boonseng WE, Oksuz O, Cook EB, et al. 2014. EWS-FLI1 utilizes divergent chromatin remodeling mechanisms to directly activate or repress enhancer elements in Ewing sarcoma. Cancer Cell 26: 668-681.

Tomazou EM, Sheffield NC, Schmidl C, Schuster M, Schonegger A, Datlinger P, Kubicek S, Bock C, Kovar H. 2015. Epigenome mapping reveals distinct modes of gene regulation and widespread enhancer reprogramming by the oncogenic fusion protein EWS-FLI1. Cell Rep 10: 1082-1095. 


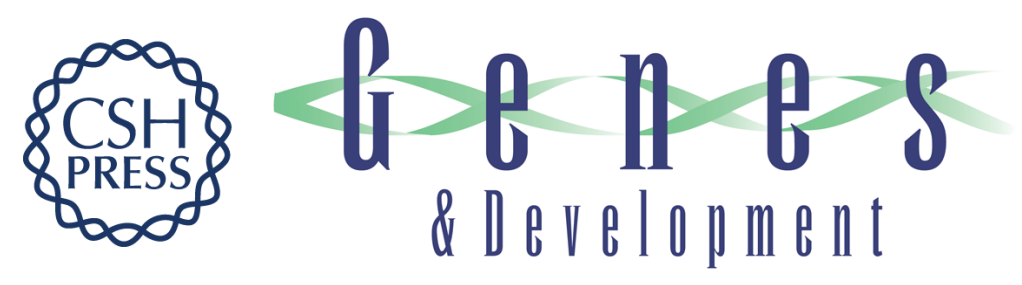

\section{Microsatellite enhancers can be targeted to impair tumorigenesis}

Kelsey E. Kaeding and Kenneth S. Zaret

Genes Dev. 2018, 32:

Access the most recent version at doi:10.1101/gad.318105.118
Related Content Epigenome editing of microsatellite repeats defines tumor-specific enhancer functions and dependencies
Gaylor Boulay, Angela Volorio, Sowmya lyer, et al.
Genes Dev. August, 2018 32: 1008-1019

References This article cites 8 articles, 2 of which can be accessed free at:

http://genesdev.cshlp.org/content/32/15-16/991.full.html\#ref-list-1

Articles cited in:

http://genesdev.cshlp.org/content/32/15-16/991.full.html\#related-urls

Creative This article is distributed exclusively by Cold Spring Harbor Laboratory Press for the first Commons

License

six months after the full-issue publication date (see

http://genesdev.cshlp.org/site/misc/terms.xhtml). After six months, it is available under a Creative Commons License (Attribution-NonCommercial 4.0 International), as described at http://creativecommons.org/licenses/by-nc/4.0/.

Email Alerting

Receive free email alerts when new articles cite this article - sign up in the box at the top

Service

right corner of the article or click here.

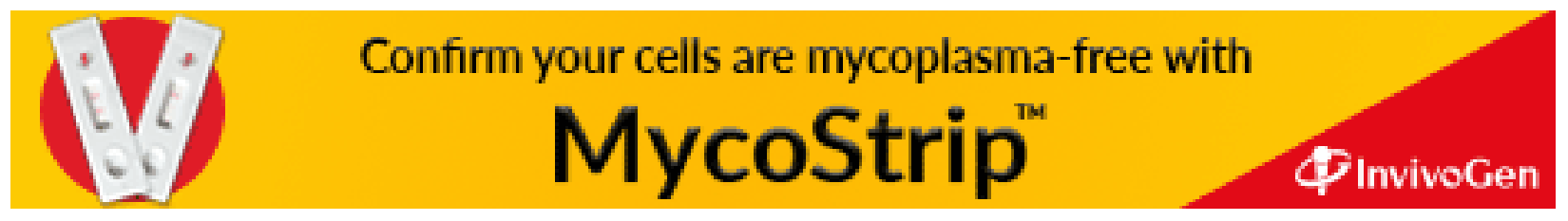

